\title{
The Potential of Mangrove Forest as Natural Tourism Area Based on the Flora-Fauna Characteristics and Social Aspect Case Study: Mangrove forest in Angsana Village
}

\author{
Kissinger ${ }^{1,2 *}$, Noor Alfi Syahrin ${ }^{2}$, Rina Muhayah NP. ${ }^{1}$, Violet ${ }^{1}$ \\ ${ }^{1}$ Faculty of Forestry, Lambung Mangkurat University Banjarbaru, South Kalimantan, Indonesia \\ ${ }^{2}$ Magister Program of Natural Resources and Environtmental Management Lambung Mangkurat University Banjarbaru, South \\ Kalimantan Indonesia
}

\begin{abstract}
Mangrove forests as natural resources have potential value as natural tourism. This research aims to analyze the potential of mangroves based on the ecological perspective of flora fauna and socio-cultural to be a natural tourism area. The object of this research is the mangrove forest and its resources. The research location was Angsana Village, Angsana District, Tanah Bumbu Regency, South Kalimantan Province, Indonesia. The equipment used was a set of survey tools and questionnaires. The flora and fauna characteristics of the mangrove forest were determined by the species compositions analysis with a tabulation matrix method. The socio-cultural aspects were analyzed descriptively. The potential of mangrove forests as natural tourism was analyzed using a tabulation matrix and narrative descriptive. The composition of tree species as a whole consisted of 14 species. There were 19 species of birds, 6 species of mammals, and 7 species of fish found in the mangrove forest area. The community strongly agree that mangroves can be used as a tourist area. Angsana Village has mangrove vegetation around the river which has approximately $43.61 \mathrm{Ha}$ in size was naturally undisturbed and accessible by a road. The mangrove forest of the village of Angsana is estimated about 200 meters far from Angsana Beach. Based on an analysis of the potential of mangrove forests, this area has the potentials to be developed as natural tourism and even ecotourism. Mangrove natural tourism area can be developed as additional tourism objects that are already running from Angsana Beach tourist destinations.
\end{abstract}

\section{Introduction}

Natural tourism is a tourism activity where there are interactions between recreational activities and conservation development. Natural tourism can improve the welfare of the community by reorganizing a variety of potential natural resources in a sustainable manner that is supported ecologically, economically, and socially to the environment and surrounding communities [1]. The principles of natural tourism are minimizing impact, fostering environmental and cultural awareness, providing positive experiences to tourists (visitors) and hosts, providing benefits, and empowerment of local communities. Natural tourism in environmental development is a mission of developing alternative tourism that does not cause many negative impacts, both on the environment and socio-cultural conditions.

Mangroves are forest areas found along coastlines, coasts, or along rivers that are affected by seawater. Mangrove forests as natural resources have biodiversity that provides benefits for human life. Utilization of these products and services has provided additional income and is even a major income in meeting the needs of people's lives. One of the services obtained from the benefits of mangrove forests is in the form of natural tourism services [2]. Mangrove forest natural tourism based on an economic perspective is an alternative livelihood for coastal communities that can increase community income. the active participation of the stakeholders is very important. Natural tourism projects can be successful if stakeholders carry out their participation in tourism management and mangrove forest conservation [3].

Nature tourism activities can be carried out by the participation of surrounding community groups as a major component in driving the conservation of mangrove ecosystems [4]. This will be able to encourage the economic growth of coastal communities and can increase public awareness of the importance of preserving the mangrove ecosystem. Ecosystem sustainability is very meaningful for the lives of present and future generations.

Mangrove ecosystems in some areas have not been managed as a natural tourist destination, so a study of the need to do a study of the conditions of various aspects related to ecology, socio-economic and cultural communities. This research was conducted in the village of Angsana, Angsana District, Tanah Bumbu Regency, South Kalimantan Province. This research aims to analyze the potential of mang roves based on the ecological perspective of flora fauna and socioeconomic communities to be developed as a natural tourism area. 


\section{Methods}

\subsection{Object, Location, and Research}

\subsubsection{Equipment}

The object of this research is the mangrove forest and all its resources. The research location was Angsana Village, Angsana District, Tanah Bumbu Regency, South Kalimantan Province, Indonesia. The equipment used is a set of survey tools, data processing tools, and questionnaires for interviews. The location of vegetation observation was determined purposively.

\subsection{Data Collection}

\subsubsection{Mangrove Vegetation}

Data was collected using the line transect plot method [5]. Transects were placed perpendicular to the coastline towards the land along 100 meters. Transects were separated from each other at distances of 50 meters to 100 meters and parallel to each other. A Transect position was determined using GPS. A series of sampling stations were made along the transect at intervals of 25 meters. Each transect was provided with 3 different dimension plot sizes, i.e. a plot of $10 \times 10 \mathrm{~m}^{2}$ (tree category, $>10 \mathrm{~cm}$ in diameter), $5 \times 5 \mathrm{~m}^{2}$ (sapling category, 2-10 cm diameter), and $2 \times 2 \mathrm{~m}^{2}$ (seedling category, diameter $<2 \mathrm{~cm}$ )

\subsubsection{Community Social Data}

The data collection method used the PRA (Participatory Rural Appraisal) approach. The research design used was descriptive qualitative [6]. Data were collected directly from data sources through the distribution of questionnaires and interviews with local communities. Respondents to fill the questionnaire are determined based on the objectives to be obtained from the respondent. Interviews were conducted in a semistructured way to key informants

\subsubsection{Data Analysis}

The characteristics of flora \& fauna of the mangrove forest were determined by the composition of flora and fauna. The species compositions were analyzed by a tabulation matrix. Socio-cultural and economic characteristics of the community were analyzed descriptively and narratively. The potential of mangrove forests to be developed as natural tourism was analyzed using a tabulation matrix and narrative descriptive analys is.

\section{RESULT AND DISCUSSION}

\subsection{Characteristics of the Flora and Fauna}

The characteristics of flora indicated by species trees. The composition of species trees found as a whole is 14 species. 7 species of mangrove were found in the observation plot and 7 additional species were found outside the observation plot. 7 species of mangrove plants found in the observation plot were Rhizophora mucronata, Rizhophora apiculata, Ceriops tagal, Bruguiera sexangula, Bruguiera gymnorhiza, Xylocarpus granatum, and Avicennia marina. Seven species of mangroves identified outside the plot were Sonneratia alba, Ceriops decandra, Lumnitzera littorea, Acanthus abracteatus, Nypa fruticans, Pandanus odoratissimus, and Aegiceras corniculatum. The 14 plant species found indicate that the mangrove forest in the village of Angsana is quite good. The existence of these tree species indicates the zonation of mangrove areas from the highest to the lowest tide levels. Some bird species found in the mangrove forest area are listed in Table 1.

Table 1. The composition of bird species in the mangrove

\begin{tabular}{clcl} 
& & \multicolumn{2}{c}{ forest } \\
\hline No & Species of birds & No & \multicolumn{1}{c}{ Species of birds } \\
\hline 1 & Egretta alba & 11 & Centropus bengalensis \\
2 & Alcedo coerulescens & 12 & Sterna hirundo \\
3 & Alcedo mininting & 13 & Haliastur indus \\
4 & Geopelia striata & 14 & Orthotomus sutorius \\
5 & Dendrocygninae sp. & 15 & Prinia familiaris \\
6 & Treron vernans & 16 & Nectarinia jugularis \\
7 & Spilopelia chinensis & 17 & Phaenocophaeus \\
& & & diardi \\
8 & Gracula religios & 18 & Butorides striatus \\
9 & Amaurornis & 19 & Tringa hypoleucos \\
& phoenicurus & & \\
10 & Ciconia sp. & &
\end{tabular}

Mangroves are important habitats for various species of birds including migratory birds. Besides, mammals are also an important species in mangrove forests. There are several mammals commonly found in mangrove forests. The species of mammals found in mangrove forests are Macaca fascicularis, Nasalis larvatus, Sus barbatus, Paradoxurus hermaphroditus, Scandentia sp, and Pteropus spp.

Few species of mammals are found in mangrove forests. This relates to the physical characteristics of the region and the availability of feed for various mammals. Various foods such as grasses and other undergrowth which are common food for herbivores from the mammal group are not found in mangrove forests. This has an impact on the limited number of mammals that can be found. Primate class mammals that can eat leaves or fruit from trees can make mangroves as their habitat. Nasalis larvatus is one of the unique species of Borneo primates lives in mangrove forests. N. larvatus is a protected species of fauna 
The mangrove forest is a preferred habitat for various species of fish to find food, nesting place, and live. Most fish that live in mangroves are also found in the sea around the coast. This fish lives in mangroves at certain times, for example when young and mating season. Food availability and protection are important factors that cause fish to migrate in and out of the mangrove environment. Fish species found in the Angsana mangrove forest area are Chanos chanos, Lutjanus campechanus, Lates calcarifer, Periopthalmus sp., Channa striata, Tilapia spp., Scylla spp. Several species of fish were found based on observations and other species of fish obtained based on information from the surrounding community.

\subsection{Socio-Cultural Characteristics of Communities Around Mangrove Forests}

The ethnic group in Angsana are Banjar (80\%), Bugis $10 \%$, and Javanese 10\%. All Angsana villagers are Muslim. The level of community awareness is very high. Formal and informal organizations are owned by the village community for both men and women. The activities of the organization went well, both on their own. Mutual cooperative activities are usually carried out such as cleaning the beach and building tourist infrastructure to improve the welfare of the community which will be used to preserve the tourism that was built together. Angsana villagers, in general, have the main livelihood as fishermen, and traders with an average income of each community were relatively low. Mangrove's ecosystem has been providing benefits to the community as a fishing ground. Some residents make mangroves as firewood sources.

Natural tourism activities can be carried out by the participation of surrounding community groups as the main component in driving the preservation of mangrove ecosystems that can encourage economic growth in coastal communities and at the same time fostering community bases on the importance of preserving mangrove ecosystems that are very meaningful for the lives of present and future generations [4].

Based on the results of interviews with the community, they strongly agree that mangroves can be used as a tourist area so that there will be an opportunity to increase community incomes as part of the multiplier effect of developing natural tourism areas. The development of natural tourism will reduce the impact of mangrove damage due to tree cutting activities. Social characteristics of the people who are accustomed to the management of Angsana beach have become a strong social capital in the development of mangrove forest nature tourism. Nature tourism projects can be successful if stakeholders carry out their role in tourism management and mangrove forest conservation [3].

\subsection{Potential of Mangrove Forest as Natural Tourism Object}

Angsana Village has an area of $64.87 \mathrm{~km} 2$, most of the area is still a mangrove forest. Some areas have been used by residents for farming rice fields, fields, settlements, open spaces, and plantations. Some of the potentials of mangrove forests in research sites that support to be used as nature tourism are presented in Table 2.

Table 2. Potentials of Mangroves as Natural Tourism Object

\begin{tabular}{|c|c|c|}
\hline No. & $\begin{array}{l}\text { The potential of } \\
\text { mangrove resources }\end{array}$ & Explanation \\
\hline \multirow[t]{6}{*}{1} & Biophysical aspects & \\
\hline & $\begin{array}{l}\text { Diversity of Plant } \\
\text { Species }\end{array}$ & $\begin{array}{l}\text { Great potential, ideal } \\
\text { with certain spots, can be } \\
\text { a revegetation area for } \\
\text { visitors }\end{array}$ \\
\hline & $\begin{array}{l}\text { Mangrove forest area is } \\
\text { relatively wide }\end{array}$ & $\begin{array}{l}\text { Great potential and can } \\
\text { be used as natural } \\
\text { attractions }\end{array}$ \\
\hline & $\begin{array}{l}\text { the number and } \\
\text { diversity of fish }\end{array}$ & As a fishing spot \\
\hline & $\begin{array}{l}\text { the number and } \\
\text { diversity of fauna }\end{array}$ & $\begin{array}{l}\text { Great potential as an } \\
\text { animal attraction and } \\
\text { educational facility }\end{array}$ \\
\hline & $\begin{array}{l}\text { The beauty of the river } \\
\text { flow and the scenery } \\
\text { around the mangrove }\end{array}$ & $\begin{array}{l}\text { photograph area, fresh } \\
\text { air, and calmness }\end{array}$ \\
\hline \multirow[t]{5}{*}{2} & Social Aspects & \\
\hline & $\begin{array}{l}\text { Daily behaviors and } \\
\text { norms of community } \\
\text { that can work together }\end{array}$ & $\begin{array}{l}\text { High potential for nature } \\
\text { tourism as a business } \\
\text { service }\end{array}$ \\
\hline & $\begin{array}{l}\text { Low economic level of } \\
\text { the community }\end{array}$ & $\begin{array}{l}\text { Potential to improve the } \\
\text { economy of the } \\
\text { community }\end{array}$ \\
\hline & $\begin{array}{l}\text { Active community } \\
\text { organizations }\end{array}$ & $\begin{array}{l}\text { Become a better indicator } \\
\text { in institutional } \\
\text { development for nature } \\
\text { tourism activities }\end{array}$ \\
\hline & Tribal diversity & $\begin{array}{l}\text { Become a good indicator } \\
\text { of village openness in } \\
\text { carry ing out interactions } \\
\text { with other groups }\end{array}$ \\
\hline \multirow[t]{4}{*}{3} & Infrastructure aspects & \\
\hline & $\begin{array}{l}\text { The access road to the } \\
\text { village is paved with } \\
\text { good condition }\end{array}$ & $\begin{array}{l}\text { important things that } \\
\text { have been met from the } \\
\text { development of tourist } \\
\text { areas }\end{array}$ \\
\hline & $\begin{array}{l}\text { It has a beach tourism } \\
\text { area located near the } \\
\text { mangrove forest }\end{array}$ & $\begin{array}{l}\text { Various infrastructures } \\
\text { have been supported by } \\
\text { the existence of previous } \\
\text { tourism objects }\end{array}$ \\
\hline & & $\begin{array}{l}\text { Mangrove tourism } \\
\text { destination is a } \\
\text { diversification program } \\
\text { from the previous tourism } \\
\text { object so that it will make } \\
\text { more destinations area } \\
\text { that can be visited }\end{array}$ \\
\hline
\end{tabular}

Angsana Village has mangrove vegetation around the river with an area of $\pm 43.61 \mathrm{Ha}$, the condition is 
still natural, an access road to the mangrove area is available so that the mangrove area has the potential to be developed as a tourist attraction. Mangrove forest in the village of Angsana has a distance of \pm 200 meters from Angsana Beach. Management of mangrove ecosystems as a tourist destination has not yet become an alternative priority for coastal tourism, alternative coastal tourism that can be developed is mangrove nature touris $m$ for additional tourism activities that are running now.

Based on an analysis of the potential of mangrove forests, this area is feasible and has the potential to be developed as nature tourism and even ecotourism. This finding is following the statement of [2] which stated that mangroves can be developed as a nature tourism objects.

\section{Conclusion}

Mangrove forests and surrounding areas have potential resources which include: i) the potential of the biological environment, the physical-chemical environment, ii) the potential of the socio-economic cultural environment, and iii) the potential of infrastructure and infrastructure. The results of the analysis of the internal potential contained in mangrove forests and surrounding areas strongly indicate that it can be developed as a natural tourism area or ecotourism. Management of mangrove ecosystems diversifies tourist destinations, subsequently, it may enrich alternative coastal tourism. Mangrove nature tourism alternatives can be developed as additional tourism objects that are already running from Angsana Beach tourist destinations.

\section{References}

1. I. Nugroho, Ekowisata dan Pembangunan yang Berkelanjutan. Kementerian Pariwisata; Indonesia, (2011)

2. A. Kustanti, Management of Mangrove Forest. Institut Pertanian Bogor Press, Bogor, (2011)

3. B. Satyanarayana, P. Bhanderi, M. Debry, D. Maniatis, F. Foré, D. Badgie, K. Jammeh, C. Farcy, N. Koedam, F. Dahdouh-Guebas, AMBIO. 41:513526, (2012)

4. A. Mayudin, Eksos J. 8, 2:90-104, (2012)

5. Bengen, DG., Introduction, and Management of Mangrove Ecosystem. PKSPL-IPB. Bogor, (2000)

6. L. J. Moleong, Qualitative Research Methodology. Rev. Ed. PT. Remaja Rosdakarya, Bandung, (2012) 